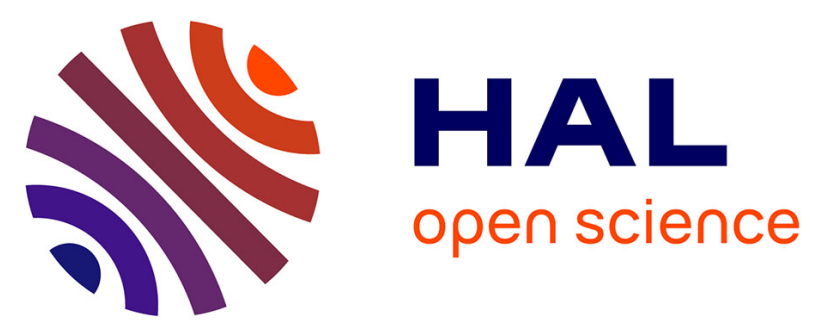

\title{
Rationally Designed Long-Wavelength Absorbing Ru(II) Polypyridyl Complexes as Photosensitizers for Photodynamic Therapy
}

Johannes Karges, Franz Heinemann, Marta Jakubaszek, Federica Maschietto, Chloé Subecz, Mazzarine Dotou, Robin Vinck, Olivier Blacque, Mickaël F Tharaud, Bruno Goud, et al.

\section{To cite this version:}

Johannes Karges, Franz Heinemann, Marta Jakubaszek, Federica Maschietto, Chloé Subecz, et al.. Rationally Designed Long-Wavelength Absorbing Ru(II) Polypyridyl Complexes as Photosensitizers for Photodynamic Therapy. Journal of the American Chemical Society, 2020, 142 (14), pp.6578-6587. 10.1021/jacs.9b13620 . insu-02892038

\section{HAL Id: insu-02892038 \\ https://hal-insu.archives-ouvertes.fr/insu-02892038}

Submitted on 12 Nov 2020

HAL is a multi-disciplinary open access archive for the deposit and dissemination of scientific research documents, whether they are published or not. The documents may come from teaching and research institutions in France or abroad, or from public or private research centers.
L'archive ouverte pluridisciplinaire HAL, est destinée au dépôt et à la diffusion de documents scientifiques de niveau recherche, publiés ou non, émanant des établissements d'enseignement et de recherche français ou étrangers, des laboratoires publics ou privés. 


\title{
Rationally Designed Long-Wavelength Absorbing Ru(II) Polypyridyl Complexes as Photosensitizers for Photodynamic Therapy
}

\author{
Johannes Karges, ${ }^{\dagger}$ Franz Heinemann, ${ }^{\dagger, \ddagger}$ Marta Jakubaszek, ${ }^{\dagger, \uparrow}$ Federica Maschietto, ${ }^{\S}$ Chloé Subecz, ${ }^{\dagger}$ \\ Mazzarine Dotou, ${ }^{\dagger}$ Robin Vinck, ${ }^{\dagger}$ Olivier Blacque, ${ }^{\ddagger}$ Mickaël Tharaud, ${ }^{\$}$ Bruno Goud,${ }^{\mathbb{I}}$ Emilio Viñuelas \\ Zahínos, ${ }^{\perp}$ Bernhard Spingler, ${ }^{*, *}$ Ilaria Ciofini, ${ }^{\S, *}$ and Gilles Gasser ${ }^{\dagger, *}$
}

$\dagger$ Chimie ParisTech, PSL University, CNRS, Institute of Chemistry for Life and Health Sciences, Laboratory for Inorganic Chemical Biology, 75005 Paris, France.

$\ddagger$ Department of Chemistry, University of Zurich, Winterthurerstrasse 190, 8057, Zurich, Switzerland.

ฯ Institut Curie, PSL University, CNRS UMR 144, 75005 Paris, France.

$\S$ Chimie ParisTech, PSL University, CNRS, Institute of Chemistry for Life and Health Sciences, Theoretical Chemistry and Modelling, 75005 Paris, France.

\$ Université de Paris, Institut de physique du globe de Paris, CNRS, F-75005 Paris, France.

$\perp$ Departamento de Química Orgánica e Inorgánica, Facultad de Ciencias, Universidad de Extremadura, 06071 Badajoz, Spain.

KEYWORDS: Anticancer, Bioinorganic Chemistry, Medicinal Inorganic Chemistry, Metals in Medicine, Photodynamic Therapy.

\begin{abstract}
The utilization of Photodynamic Therapy (PDT) for the treatment of various types of cancer has gained increasing attention over the last decades. Despite the clinical success of approved photosensitizers (PSs), their application is limited due to poor water solubility, aggregation, photodegradation, and slow clearance from the body. To overcome these drawbacks, research efforts are devoted towards the development of metal complexes and especially $\mathrm{Ru}(\mathrm{II})$ polypyridine complexes based on their attractive photophysical and biological properties. Despite the recent research developments, the vast majority of complexes utilize blue or UV-A light to obtain a PDT effect, limiting the penetration depth inside the tissue and therefore, the possibility to treat deep-seated or large tumors. To circumvent these drawbacks, we present the first example of the DFT guided search for efficient PDT PSs with a substantial spectral red shift towards the biological spectral window. Thanks to this design, we have unveiled a $\mathrm{Ru}(\mathrm{II})$ polypyridine complex, which causes phototoxicity in the very-low micromolar-to-nanomolar range at clinically relevant 595 $\mathrm{nm}$, in monolayer cells as well as in 3D multicellular tumor spheroids.
\end{abstract}

\section{INTRODUCTION}

Photodynamic Therapy (PDT) is a non-invasive medical technique for the treatment of various types of cancer (e.g., lung, bladder, esophageal, and brain cancer) as well as bacterial, fungal or viral infections. The effect of PDT relies on the combination of an ideally non-toxic molecule, a so-called photosensitizer (PS), oxygen, and light. The PS is injected either systemically or locally. Upon light irradiation, the PS is uplifted to an excited singlet state from which the PS can undergo an intersystem crossing process to reach an excited triplet state. This state can influence the biological environment either by a Type I or Type II pathway. A Type I mechanism is characterized by an electron or proton transfer from or to the PS, which leads to the formation of reactive oxygen species (ROS) or other highly reactive radicals. In a Type II mechanism, the energy is transferred to triplet oxygen $\left({ }^{3} \mathrm{O}_{2}\right)$ to generate singlet oxygen $\left({ }^{1} \mathrm{O}_{2}\right)$. Due to their high reactivity,
ROS and ${ }^{1} \mathrm{O}_{2}$ can cause oxidative stress and damage in different cellular compartments (i.e., membrane, nucleus, endoplasmic reticulum, lysosome, mitochondria). Both of these mechanisms can happen simultaneously upon light irradiation even so Type II pathway is the predominant one for most approved PSs. ${ }^{1-6}$

Photofrin is the most commonly used PS in PDT. It has been approved for the treatment of bladder cancer, early-stage lung cancer, esophageal cancer, and early non-small cell lung cancer. However, based on its low solubility and low absorption in the therapeutic window (i.e., 600-900 nm), high concentrations, as well as high light doses are required for an adequate tumor treatment making Photofrin not an ideal PS. Additionally, it was shown that this PS has an exceptionally long half-life excretion time leading to severe photosensitivity for the patients. Since the majority of investigated and approved PS are based on a tetrapyrrolic scaff old (i.e., porphyrins, chlorins, 
phthalocyanines), these PSs are likely to have similar drawbacks which include 1) poor water solubility; 2) tedious synthesis and purification; 3) low cancer selectivity; 4) photobleaching effect and 5) slow clearance from the body causing photosensitivity. Therefore, a need for modification of existing PSs or the development of new classes of PSs is needed. $^{7-14}$

Among the new classes of PSs investigated the development of $\mathrm{Ru}(\mathrm{II})$ polypyridyl complexes as PDT PSs has received much attention due to their ideal photophysical and photochemical properties (i.e., high water solubility, high chemical stability and photostability, intense luminescence, large Stokes shifts, high ${ }^{1} \mathrm{O}_{2}$ production). ${ }^{15-30}$ Worthy of note, the complex TLD-1433 $\left[\mathrm{Ru}(\mathrm{dmb})_{2}(\mathrm{IP}-\mathrm{TT})\right]^{2+} \quad\left(\mathrm{dmb}=4,4^{\prime}\right.$-dimethyl-2,2'bipyridine, IP-TT=2-(2',2":5",2' "'-terthiophene $)$-imidazol[4,5f][1,10]phenanthroline) has just entered phase II clinical trial as a PDT PS for the treatment of non-muscle invasive bladder cancer in Canada. ${ }^{31-34}$ Despite these remarkable properties, the majority of Ru(II)-based PS are typically excited using blue or UV-A light and therefore suffer from a lack of absorption in the biological spectral window $(600-900 \mathrm{~nm}){ }^{35-39}$ Based on absorption and light scattering eff ects in the biological environment, the light penetration depth into the tissue is low at this wavelength, which limits their application to treat deep tumors or large tumors. ${ }^{40,41}$ To overcome this limitation, there is a need for optimization of the absorption properties of $\mathrm{Ru}(\mathrm{II})$-based PSs. It has been well-established that the photophysical properties, including absorption, emission as well as excited-state lifetimes of Ru(II) polypyridyl complexes depend on the ligands bound to the $\mathrm{Ru}$ center. This variable can, therefore, be tuned. In this context, we applied a combined experimental and theoretical approach to design new suitable Ru-based PDT PSs. Based on the already wellestablished biological activity of the complex $\left[\mathrm{Ru}(\mathrm{phen})_{3}\right]^{2+}$ (phen $=1,10$-phenanthroline) as a minor groove binder ${ }^{42}$ and $\left[\mathrm{Ru}(\mathrm{bphen})_{3}\right]^{2+}$ (bphen $=4,7$-diphenyl-1,10-phenanthroline) as a mitochondria and lysosome targeting agent ${ }^{43}$ and their ability to be effective PDT $\mathrm{PSs}^{44-46}$, we decided to use $\left[\mathrm{Ru}(\text { phen })_{2}(\text { bipy })\right]^{2+}$ and $\left[\mathrm{Ru}(\text { bphen })_{2}(\text { bipy })\right]^{2+}\left(\right.$ bipy $=2,2^{\prime}-$ bipyridine) derivatives as basic scaffolds. In this investigation, the electronic properties, the origin, and the magnitude of red shift towards the biologic spectral window are disclosed. The resulting complexes (1-7, Figure 1) were synthesized, characterized, and biologically evaluated in-depth. Thanks to this combined study, a highly active Ru(II)-based PDT PS that can be excited up to $595 \mathrm{~nm}$ could be unveiled.

\section{RESULTS AND DISCUSSION}

Rational Design. As the basis of the design of $\mathrm{Ru}(\mathrm{II})$ polypyridine complexes as PDT PSs with red-shifted absorption near or in the biological spectral window, the $\left[\mathrm{Ru}(\text { phen })_{2} \text { (bipy) }\right]^{2+}$ scaffold was used due to its synthetic accessibility and generally high physical stability. To pursue this aim, systematic modification on the bipyridine moiety was investigated, and these effects studied by a theoretical and experimental approach.

It is well known that, in a simplified picture, the highest occupied orbitals in a pseudo-octahedral $\mathrm{Ru}(\mathrm{II})$ polypyridyl complex are mainly consisting of the Ruthenium $t_{2 \mathrm{~g}}$ - $d$-orbitals while the lowest occupied orbitals typically correspond to $\pi^{*}$-orbitals localized on the ligands. ${ }^{47,48}$ Therefore, the lowest intense absorption band is expected to be of metal to ligand charge transfer (MLCT) character stemming from electronic transitions from the $t_{2 g}$ manifold to the empty ligands lowestlying orbitals and leading to the population of a singlet state of MLCT nature under light irradiation. A simple way to red shift the MLCT absorption energy is, therefore, to decrease the HOMO-LUMO gap by an ad-hoc functionalization of the ligands. In particular, functionalization of the ligands with electron-donating and electron-withdrawing (EDG/EWG) groups is expected to increase the occupied MOs and lower the LUMO energy, respectively.

In the case of the unsubstituted compound $\mathbf{1}$, the ligands are not strictly equivalent (two phen and one bipy ligand) so that the $t_{2 g}$ orbitals are not expected to be strictly degenerate. Nonetheless, from the computed MOs energies of $\mathbf{1}$, it can be seen that the difference in energy between the $t_{2 g}$ orbitals is very tiny (roughly $0.04 \mathrm{eV}$ ) and the same holds for the LUMOs of $\pi^{*}$ character (roughly $0.08 \mathrm{eV}$ ) with contributions arising both from the phen and the bipy ligands. As a consequence, the functionalization of any of the two ligands shall induce a shift of the gap but is indeed expected to be easier in the case of the bipy, due to the reduced steric congestion around this ligand. For this reason, EDGs and EWGs were exclusively introduced only on the bipy ligand (1-5, Figure 1, optimized cartesian coordinates Table S1-S5).

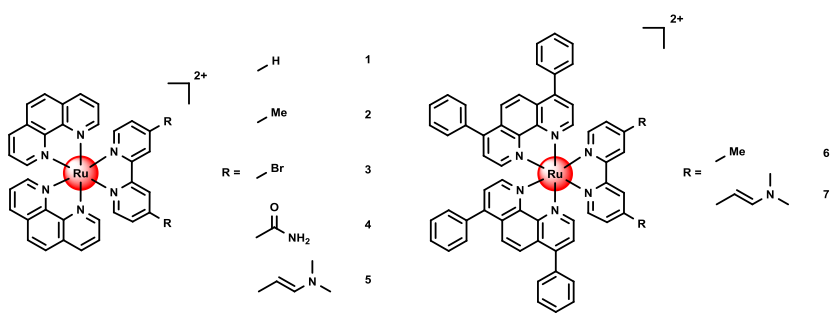

Figure 1. Chemical structures of the $\mathrm{Ru}(\mathrm{II})$ polypyridyl complexes investigated in this work. The complexes 1-7 were isolated as $\mathrm{PF}_{6}^{-}$salts.

For this purpose, the energies of the frontier molecular orbitals were computed (Figure 2). Indeed, functionalization with -Me (2) (a weakly EDG) only negligibly affects the gap (reducing from $3.99 \mathrm{eV}$ for $\mathbf{1}$ to $3.97 \mathrm{eV}$ for $\mathbf{2}$ ). A slightly more significant effect is obtained by weak EWGs such as $-\mathrm{Br}(3)$ and $\mathrm{CONH}_{2}(4,3.83 \mathrm{eV}$, and $3.77 \mathrm{eV}$, respectively), which induce a small stabilization of the LUMO. These observations are in line with the results previously obtained by some of us ${ }^{49}$ when functionalizing with a -CHO group, a better EWG for which the computed gap is indeed $3.47 \mathrm{eV}$. On the other hand, functionalization with the vinyl dimethylamine-EDG (5) results in a substantial reduction of the HOMO-LUMO gap (to $3.24 \mathrm{eV}$, roughly $0.7 \mathrm{eV}$ lower than the native compound (1) due to a sizable increase of the HOMO energy. Nonetheless, it should be underlined that the gap is reduced here due to the presence of occupied orbitals centered on the vinyl dimethylamine group in the gap. Therefore, although de facto the gap is substantially reduced, there is no destabilization of the $t_{2 \mathrm{~g}}$ manifold so that the bright MLCT transition (occurring from the $t_{2 \mathrm{~g}}$ orbitals to the $\pi^{*}$ ligand orbitals) is expected not to be affected (that is red-shifted).

To capitalize on this theoretical insight, we additionally examined the functionalization with a methyl and vinyl dimethylamine group on the $\left[\mathrm{Ru}(\mathrm{bphen})_{2} \text { (bipy) }\right]^{2+}$ scaffold 6-7 (optimized cartesian coordinates Table S6-S7). Interestingly, changing the ligand scaffold from phen to bphen does not significantly affect the gap - as expected due to the small 
electronic effect induced by the presence of the four phenyl groups on the phen ligands. Indeed comparing compounds 2 and $\mathbf{6}$ or 5 and 7 (that are the analogous in the two series), a difference of only 0.1 and $0.07 \mathrm{eV}$ in the gap, respectively, can be observed. Overall the theoretical insight revealed that the vinyl dimethylamine functionalized $(\mathbf{5 , 7})$ and bphen coordinated (6-7) complexes showed the strongest spectral red shift.

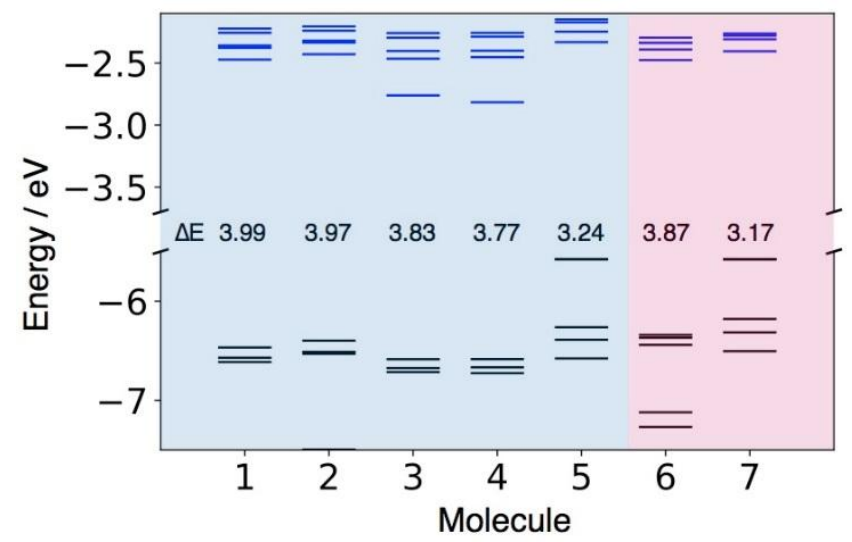

Figure 2. Computed frontier orbitals' energies and HOMOLUMO gaps (in eV). Occupied/virtual orbitals energies are represented as black/blue line. Blue background: $\mathrm{Ru}(\mathrm{phen})_{2}(\mathrm{bipy})^{2+}$ skeleton. Purple background: Ru(bphen $)_{2}(\text { bipy })^{2+}$ skeleton.

Synthesis and Characterization. Based on the theoretical design, the $\mathrm{Ru}(\mathrm{II})$ polypyridine complexes 1-7 (Figure 1) were synthesized. To date, the synthesis of complexes 3-5 and $\mathbf{7}$ has not been yet reported, while complexes $\mathbf{1}^{50}, \mathbf{2}^{51}$, and $\mathbf{6}^{52}$ are known. However, in this study, slightly different experimental procedures than the previously described were employed to obtain these compounds (for experimental protocols see supporting information). The identity of all complexes was confirmed by ${ }^{1} \mathrm{H},{ }^{13} \mathrm{C}-\mathrm{NMR}$ (Scheme $\mathrm{S} 1$, Figures S1-S14), HRMS, and the purity by elemental analysis. In addition, the molecular structures of complexes 1-3 (Figure S15-17, Table S8-S9) were confirmed by single-crystal X-ray diffraction studies. The crystal structure of compound 1 has already been characterized by Huang and Ogawa ${ }^{53}$, with the exception that the crystal structure presented here contains one solvent molecule of acetonitrile per ruthenium complex. In all molecular structures, the $\mathrm{Ru}(\mathrm{II})$ central atom adopts a distorted octahedral geometry chelated by two 1,10-phenanthroline ligands and one 2,2'-bipyridine ligand with $\mathrm{Ru}-\mathrm{N}$ bond lengths ranging from 2.046(3) to 2.078(3) $\AA, \mathrm{N}_{\text {phen }}-\mathrm{Ru}-\mathrm{N}_{\text {phen }}$ angles from $79.48(12)$ to $80.1(2)^{\circ}$, and $\mathrm{N}_{\text {bipy }}-\mathrm{Ru}-\mathrm{N}_{\text {bipy }}$ angles from $78.55(10)$ to $78.98(13)^{\circ}$. It is worth to note that the substitution of the bipyridine ligand by methyl groups in $\mathbf{2}$ and bromo ligands in $\mathbf{3}$ has no significant influence on the $\mathrm{Ru}-\mathrm{N}$ bond distances.

Photophysical properties. The absorption spectra of the compounds 1-7 were measured in $\mathrm{CH}_{3} \mathrm{CN}$ (Figure S19, Table 1) and compared with the computed spectra (Figure 3). Although in the simulated spectra the energy of the MLCT band (around $450 \mathrm{~nm}$ ) is systematically overestimated while the higher energy ligand centered (LE) band (around $300 \mathrm{~nm}$ ) is better reproduced, small shifts towards the spectral windows of interest and a rise in intensity for the lowest energy band is indeed observed for the compounds 5, 6 and 7. Of note, in the case of $\mathbf{5}$ and $\mathbf{7}$, several electronic transitions are computed to contribute to the first -lowest energy- absorption band. The most intense has still an MLCT character while the one occurring at lower energy (less intense than those of MLCT character) and responsible for the tail and red-shift of the band are predicted to be essentially
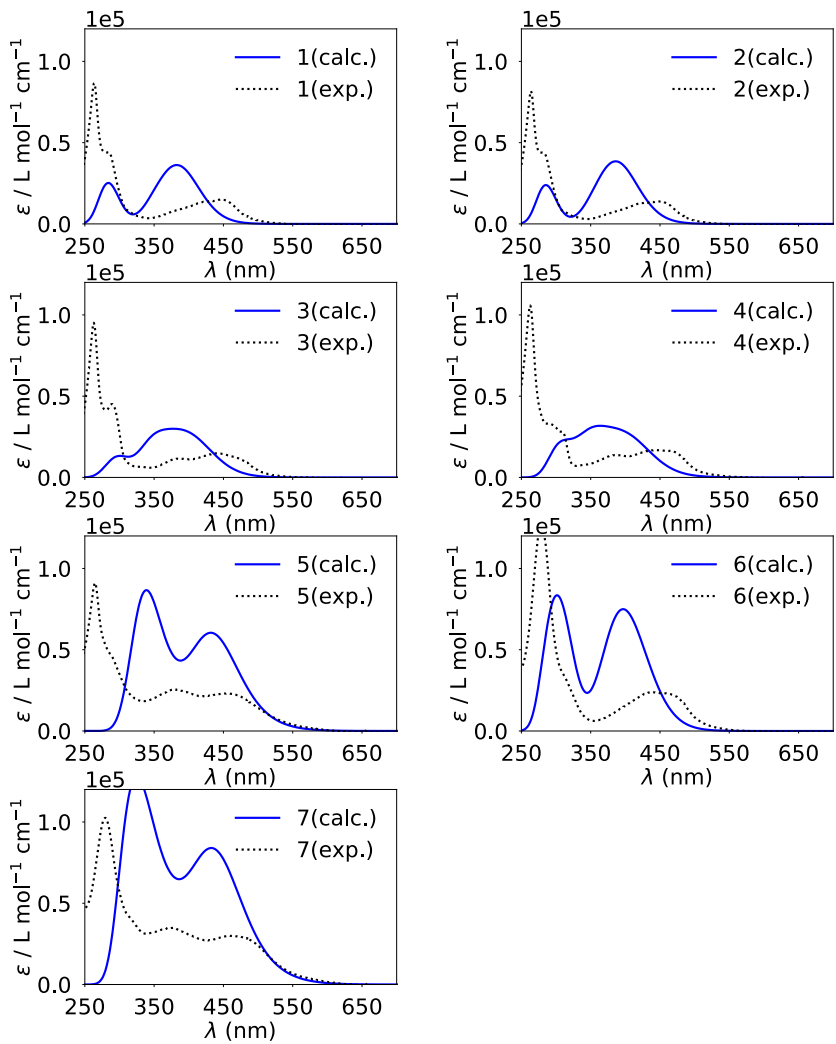

Figure 3. Simulated (blue) and experimental (black) spectra of compounds 1-7 in $\mathrm{CH}_{3} \mathrm{CN}(\mathrm{c}=7.5 \mu \mathrm{M})$. Computed vertical electronic transitions are depicted as vertical blue bars. Corresponding oscillator strength $(f)$ is given in a.u.

ligand centered. These transitions are indeed of HOMOLUMO type and, as discussed above, corresponding essentially to a transition from the vinyl dimethylamine group to the $\pi^{*}$ orbitals of the ligand. This can be visualized and understood from the maps of the difference in density between ground (GS) and excited state (ES) for two representative transitions of compound 6 (Figure S18a) and 7 (Figure S18b). For both complexes, the lowest energy transition (first electronic transition ES1) and the most intense one contributing to the first band (ES 4 and ES 9 for $\mathbf{6}$ and 7, respectively) were analyzed. In Figure S18, density depletion/increase regions upon excitation for each are represented by blue/yellow zones, and the barycenters of these regions - depicted as blue/yellow dots can be interpreted as the position of the electron and hole upon excitation. It can be clearly seen that while for complex $\mathbf{6}$, both transitions have a clear MLCT character though not necessarily involving the same ligand, in the case of 7, in agreement with the MO diagram, the lowest energy transition is of interligand type and mostly involving the vinyl dimethylamine-part. Therefore, even if a redshift of the first absorption band is predicted and indeed experimentally observed, it is not necessarily expected to correlate with an improvement of the phototherapeutic properties that are indeed linked to the population of a MLCT state. Following this, the luminescence of the $\mathrm{Ru}(\mathrm{II})$ polypyridine complexes upon 
excitation at $355 \mathrm{~nm}$ was investigated. The maxima of the emission signals (Figure S20) were measured and found to be between $600-710 \mathrm{~nm}$. Interestingly, complexes5 and 7, which showed the highest red shift in absorption, also demonstrated the strongest red shift in their emission maximum. The eration of singlet oxygen $\left({ }^{1} \mathrm{O}_{2}\right)$ was quantitatively measured upon excitation at $450 \mathrm{~nm}$ by two complementary methods: (i) direct by measurement of the phosphorescence of ${ }^{1} \mathrm{O}_{2}$, (ii) indirect by temporal monitoring the change of absorption of a ${ }^{1} \mathrm{O}_{2}$ scavenger. ${ }^{58,59}$ Complexes 1-4, 6 were found to have ${ }^{1} \mathrm{O}_{2}$ quantum yields (Table 1) between 53-69\% in $\mathrm{CH}_{3} \mathrm{CN}$ and 5-

Table 1. Spectroscopic properties of compounds 1-7 in $\mathrm{CH}_{3} \mathrm{CN}$. Singlet oxygen quantum yields of compounds 1-7 in $\mathrm{CH}_{3} \mathrm{CN}$ and aqueous solution determined by direct and indirect methods by excitation at $450 \mathrm{~nm}$. Average of three independent measurements, $\pm 10 \%$.

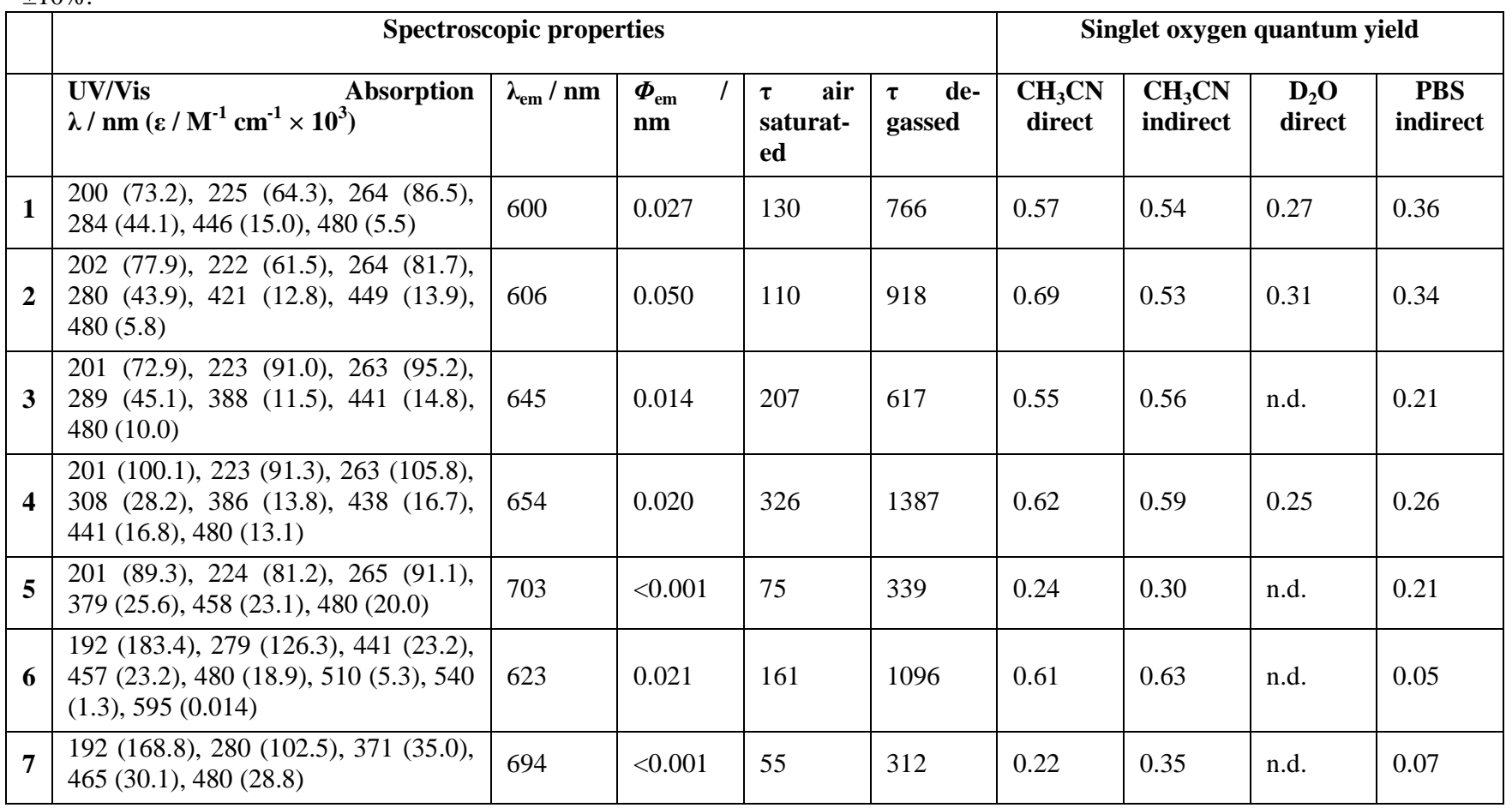

comparison of the excitation and absorption spectra of all compounds showed no significant differences. All complexes demonstrated a large Stokes shift implying minimal inference between excitation and emission. The luminescence quantum yields were found with values between $5.0 \%-1.4 \%$ (Table S10) for 1-4, 6 and are therefore in the same range then other $\mathrm{Ru}(\mathrm{II})$ polypyridine complexes. ${ }^{54,55}$ On the contrary, the luminescence of $\mathbf{5}$ and $\mathbf{7}$ were barely measurable - with luminescence quantum yields $>0.1 \%$. This is consistent with the computed vertical absorption (see before) highlighting that for these two complexes the lowest lying excited states are of LC character. This result is also in agreement with the exceptionally low luminescence quantum yield of $\left(E, E^{\prime}\right)-4,4^{\prime}$-bis $\left(N, N^{\prime}-\right.$ dimethylaminovinyl)-2,2'-bipyridine in dichloromethane $(1.5 \%)$ in comparison to other substituted 2,2'-bipyridines ${ }^{56}$ and of the $\left[\mathrm{Ru}\left(\left(E, E^{\prime}\right)-4,4^{\prime}\right.\right.$-bis $\left(N, N^{\prime}\right.$-dimethylaminovinyl)2,2'-bipyri-dine $\left.)_{3}\right]^{2+}$ complex in $\mathrm{CH}_{3} \mathrm{CN}(>0.1 \%),{ }^{57}$ which were recently reported. The excited-state lifetimes were determined in degassed and air-saturated $\mathrm{CH}_{3} \mathrm{CN}$ solution to investigate the influence of the presence of oxygen. The obtained values (Figure S21-S27, Table 1) were found to be in the nanosecond scale in a degassed $(312-1387 \mathrm{~ns})$ and air saturated ( 55 - $326 \mathrm{~ns})$ solution. All measured lifetimes were found to be in the same range as for other $\mathrm{Ru}(\mathrm{II})$ polypyridine complexes. $^{54,55}$ Importantly, the data shows that the presence of oxygen has a significant influence on the lifetime of the excited state for all complexes indicating that molecular oxygen can interact with the triplet state of the complex. The gen-
$36 \%$ in an aqueous solution, suggesting an application as a PDT agent. These values are comparable with those previously reported for related compounds. ${ }^{60,61}$ In comparison, the ${ }^{1} \mathrm{O}_{2}$ quantum yields of the $\left(E, E^{\prime}\right)-4,4^{\prime}$-bis $\left(N, N^{\prime}-\right.$ dimethylaminovinyl)-2,2'-bipyridine coordinated complexes 5 and 7 were found to be drastically lower with values of 22$35 \%$ in $\mathrm{CH}_{3} \mathrm{CN}$ and $7-21 \%$ in an aqueous solution. This was expected as these compounds show an untypical excited state behavior (emission, luminescence, lifetime) which is also explained by DFT calculations.

Stability. The stability of a compounds is an essential parameter for their use as a PDT agent. As a first experiment, the stability of the complexes was investigated in a DMSO solution since this solvent was shown to be problematic for certain drug (candidates). ${ }^{62-64}$ For this purpose, solutions of the complexes in DMSO- $\mathrm{d}_{6}$ were prepared and stored in a NMR tube in the dark at room temperature. A ${ }^{1} \mathrm{H}-\mathrm{NMR}$ spectrum was measured directly after preparing the solution after one, two and seven days. For complexes 1-4 and 6 (Figures S28-S31, S33), no significant change in the spectra were observed, indicating that no decomposition occurred. In contrast to this, small changes in the spectra for compounds 5 and $\mathbf{7}$ could be observed. For both compounds, changes in the signals could be detected after 7 days (Figures S32, S34). This indicates that these compounds are not stable in DMSO. To assess the compatibility of the compounds under biological conditions, the stability of the complexes was tested in pooled human plasma. The complexes were incubated for $48 \mathrm{~h}$ in the dark with coffeine as an internal standard, which was previously shown 
to be stable under these conditions ${ }^{65}$ and then analysed by HPLC (Figures S35-41). The stability of complexes 1-4 and 6 and the previously mentioned decomposition of compounds $\mathbf{5}$ and 7 were confirmed. Based on these findings, the stability of compounds 5 and 7 has been investigated more in detail by incubation of these complexes with shorter time intervals $(0 \mathrm{~h}$, $4 \mathrm{~h}, 12 \mathrm{~h}, 24 \mathrm{~h}, 48 \mathrm{~h}$ ) in the dark. 5 shows first sign of degradation after $12 \mathrm{~h}$ and compound 7 after $24 \mathrm{~h}$. The degradation of both complexes advanced in the investigated time interval, but still show unreacted complex even after $48 \mathrm{~h}$ incubation. Following this, the potential decomposition of the complexes upon light irradiation was also tested as previous studied
Table 3. $\mathrm{IC}_{50}$ values $(\mu \mathrm{M})$ for 6 in mouse colon carcinoma (CT-26) cells in the dark and upon light irradiation at $510 \mathrm{~nm}$ $\left(40 \mathrm{~min}, 10.00 \mathrm{~J} \mathrm{~cm}^{-2}\right), 540 \mathrm{~nm}\left(60 \mathrm{~min}, 14.25 \mathrm{~J} \mathrm{~cm}^{-2}\right)$ and $595 \mathrm{~nm}\left(2 \mathrm{~h}, 22.47 \mathrm{~J} \mathrm{~cm}^{-2}\right)$.

\begin{tabular}{|l|l|l|l|}
\hline $\begin{array}{c}\text { Wavelength } \\
\text { /nm }\end{array}$ & \multicolumn{1}{|c|}{ Dark } & \multicolumn{1}{|c|}{ Light } & \multicolumn{1}{|c|}{ PI } \\
\hline $510 \mathrm{~nm}$ & $4.18 \pm 0.56$ & $0.20 \pm 0.005$ & 20.6 \\
\hline $540 \mathrm{~nm}$ & $3.27 \pm 0.64$ & $0.34 \pm 0.005$ & 9.6 \\
\hline $595 \mathrm{~nm}$ & $1.41 \pm 0.003$ & $0.06 \pm 0.004$ & 23.5 \\
\hline
\end{tabular}

Table 2. $\mathrm{IC}_{50}$ values $(\mu \mathrm{M})$ for the complexes 1-7 and Protoporphyrin IX (PpIX) in mouse colon carcinoma (CT-26), human glioblastoma (U87), human glioblastoma astrocytoma (U373), human cervical carcinoma (HeLa) and non-cancerous retina pigmented epithelial (RPE1) cell lines in the dark and upon light irradiation $\left(480 \mathrm{~nm}, 10 \mathrm{~min}, 3.21 \mathrm{~J} \mathrm{~cm}^{-2}\right)$.

\begin{tabular}{|c|c|c|c|c|c|c|c|c|c|c|c|c|c|c|c|}
\hline & \multicolumn{3}{|c|}{ CT-26 } & \multicolumn{3}{|c|}{ U87 } & \multicolumn{3}{|c|}{ U373 } & \multicolumn{3}{|c|}{ HeLa } & \multicolumn{3}{|c|}{ RPE-1 } \\
\hline 1 & $>100$ & $>100$ & - & $>100$ & $\begin{array}{l}93.68 \\
\pm \\
2.50\end{array}$ & $>1$ & $>100$ & $>100$ & - & $>100$ & $>100$ & - & $>100$ & $>100$ & - \\
\hline 2 & $>100$ & $\begin{array}{l}91.24 \\
\pm 7.54\end{array}$ & $>1$ & $>100$ & $\begin{array}{l}71.40 \\
\pm \\
5.67\end{array}$ & $>1$ & $>100$ & $>100$ & - & $>100$ & $>100$ & - & $>100$ & $>100$ & - \\
\hline 3 & $>100$ & $\begin{array}{l}85.71 \\
\pm 9.47\end{array}$ & $>1$ & $>100$ & $>100$ & - & $>100$ & $>100$ & - & $>100$ & $>100$ & - & $>100$ & $>100$ & - \\
\hline 4 & $>100$ & $\begin{array}{l}72.59 \\
\pm 7.44\end{array}$ & $>1$ & $>100$ & $>100$ & - & $>100$ & $>100$ & - & $>100$ & $>100$ & - & $>100$ & $>100$ & - \\
\hline 5 & $>100$ & $\begin{array}{l}52.54 \\
\pm 6.04\end{array}$ & $>2$ & $>100$ & $>100$ & - & $>100$ & $>100$ & - & $>100$ & $>100$ & - & $>100$ & $>100$ & - \\
\hline 7 & $\begin{array}{l}94.47 \\
\pm \\
7.38\end{array}$ & $\begin{array}{l}6.62 \pm \\
0.07\end{array}$ & 14.3 & $>100$ & $\begin{array}{l}7.90 \\
\pm \\
0.54\end{array}$ & $>12.7$ & $>100$ & $\begin{array}{l}14.85 \\
\pm \\
0.81\end{array}$ & $>6.7$ & $>100$ & $\begin{array}{l}15.21 \\
\pm \\
1.29\end{array}$ & $>6.5$ & $>100$ & $\begin{array}{l}8.95 \\
\pm \\
0.50\end{array}$ & $>11.2$ \\
\hline
\end{tabular}

have shown that the stability of metal complexes could be influenced upon light exposure. ${ }^{66,67}$ This is crucially important as some of the currently approved PDT agents are associated with a strong photobleaching effect.The complexes were exposed to a continuous LED irradiation at $450 \mathrm{~nm}$ and the absorption spectra monitored. As a positive control $\left.[\mathrm{Ru} \text { (bipy) })_{3}\right] \mathrm{Cl}_{2}$ and as a negative control Protoporphyrin IX was used. The comparison of the spectra shows that complexes 1-4 and 6 (Figure S42-46, 48) have a photobleaching effect in a similar range than $\left[\mathrm{Ru}(\text { bipy })_{3}\right] \mathrm{Cl}_{2}$ (Figure S41). However, compounds $\mathbf{5}$ and $\mathbf{7}$ were found to be strongly affected by light irradiation with a loss of about half of their absorbance after one minute (Figure S47, 49). This effect is even stronger than that observed for Protoporphyrin IX (Figure S50).

Biological Evaluation. The lipophilicity/hydrophilicity of the compounds was determined by measuring the distribution coefficient $(\log P)$ between an organic octanol and aqueous phosphate buffer saline phase (Table S10). The complexes based on a $\left[\mathrm{Ru}(\mathrm{phen})_{2}(\text { bipy) }]^{2+}\right.$ scaffold (1-5) were found with $\log P$ values between $+0.2-+0.7$ and the complexes based on a $\left[\mathrm{Ru}(\text { bphen })_{2} \text { (bipy) }\right]^{2+}$ scaffold (6-7) between $+1.4-+1.7$. As all complexes were found majorly in the organic phase, their lipophilicity is indicated.
Following this, the cellular uptake of the compounds was investigated. This property is important as a PS with good photophysical properties could be still inactive due to poor cellular uptake. Amount of Ru metal accumulated inside the human cervical carcinoma (HeLa) cells upon incubation for 4 $\mathrm{h}$ at $25 \mu \mathrm{M}$ concentration was determined by inductively coupled plasma mass spectrometry (ICP-MS). As expected, the compounds 6-7 which are based on a $\left[\mathrm{Ru}(\mathrm{bphen})_{2}(\text { bipy })\right]^{2+}$ scaffold showed a 2.1-5.8 times higher cellular accumulation (Figure S51) in comparison to compounds 1-5, in agreement with their $\log P$ values. To determine the potential of the complexes to act as PDT agents, mouse colon carcinoma (CT-26), human glioblastoma (U87) human glioblastoma astrocytoma (U373), human cervical carcinoma (HeLa) as well as noncancerous retina pigmented epithelial (RPE-1) cell lines were treated with the complexes. Their cytotoxicity in the dark and upon light exposure was investigated using fluorometric cell viability assay (Table 2). Worthy of note, the light doses used during our experiments at different wavelengths were first optimised to the survival of the cells treated purely by light exposure. At the same irradiation wavelength, all cell lines were tested with the same light dose to investigate the influence on the different type of cells used and therefore explore the PS potential on different cancer types. Ideally, a PDT PS should be non-toxic in the dark and highly toxic upon light exposure. Promisingly, complexes 1-5 and 7 were found to be 
non-cytotoxic in the dark in all chosen cell lines $\left(\mathrm{IC}_{50}\right.$ $>100 \mu \mathrm{M}$ ), while compound 6 showed a cytotoxic profile in the range from 3.09 to $28.77 \mu \mathrm{M}$ in all investigated cell lines. Upon irradiation at $480 \mathrm{~nm}\left(10 \mathrm{~min}, 3.21 \mathrm{~J} \mathrm{~cm}^{-2}\right)$, no or only poor toxicity $\left(\mathrm{IC}_{50}\right.$ range from $>100$ to $\left.52.54 \mu \mathrm{M}\right)$ was observed for complexes based on a $\left[\mathrm{Ru}(\text { phen })_{2}(\text { bipy })\right]^{2+}$ scaffold (1-5). In contrast, compounds based on the $\left[\mathrm{Ru}(\mathrm{bphen})_{2}(\text { bipy })\right]^{2+}$ scaffold (6-7) showed a notable phototoxicity upon light irradiation (Phototoxic index (PI)$\mathrm{IC}_{50}$ in the dark/ $\mathrm{IC}_{50}$ in upon irradiation, ranges from 6.5 to 42.5). This effect can be attributed to the significantly higher uptake of 6 and tizers can show a phototoxic effect although its extinction coefficient is below $100 \mathrm{M}^{-1} \mathrm{~cm}^{-1}$. ${ }^{16,37}$ Overall, these results make compound $\mathbf{6}$ an impressive candidate as a PDT agent.

To have a deeper insight in the mechanism of action of compound 6, its cellular localisation in HeLa cell line was determined by confocal microscopy experiments. Even after only 5 min incubation $(14 \mu \mathrm{M})$, the complex could be detected in the cytoplasm (see Figure S52). Immunofluorescence studies with GM130 (cis-Golgy protein), TGN46 (trans-Golgy protein), KDEL (endoplasmic reticulum protein retention receptor) and LAMP (lysosome- associated membrane glycoprotein) antibodies demonstrated that compound $\mathbf{6}$ did not colocalize with a)

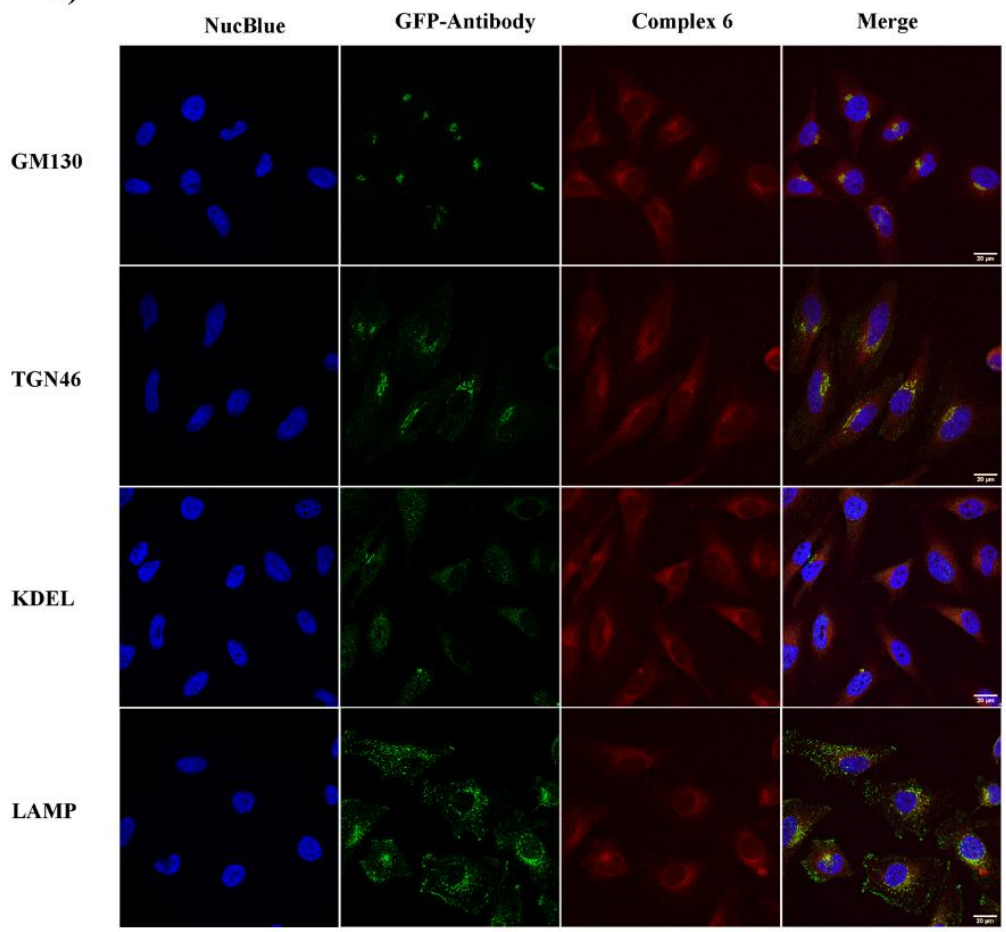

b)

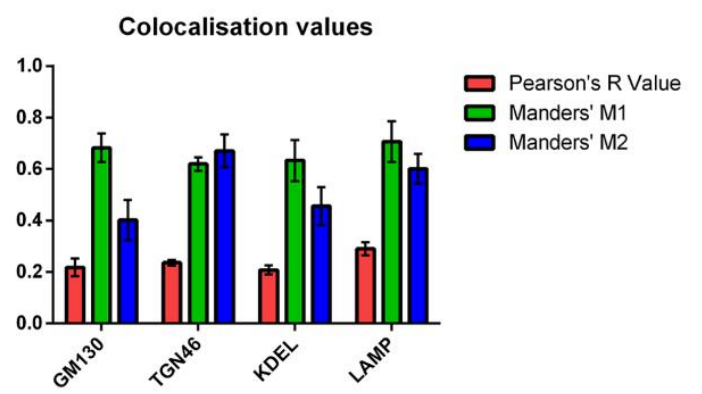

Figure 4. a) Immunofluorescent images of HeLa cells treated with complex 6 (14 $\mu \mathrm{M}, 30 \mathrm{~min})$. DNA visualised by NucBlue staining, immunofluorescence for GM130, TGN46, KDEL and LAMP proteins shown in green, complex 6 shown in red. Scale bar, $20 \mu \mathrm{m}$. b) Person's R, Manders' M1 and Manders' M2 colocalisation values obtained for complex 6 and fluorescent probes.

7. Overall, considering the instability of complex 7 in DMSO and human plasma and the absence/low phototoxicity of complexes 1-5, complex 6 was further studied.

Following this preliminary examination, the ability to cause a phototoxic effect at longer wavelengths towards the biological spectral window was further evaluated. CT-26 cell line which was previously shown to be the strongest affected by this compound was chosen for subsequent studies. Importantly, light irradiation of the treated cells at $510 \mathrm{~nm}(40 \mathrm{~min}$, $\left.10.00 \mathrm{~J} \mathrm{~cm}^{-2}\right)$ or $540 \mathrm{~nm}\left(60 \mathrm{~min}, 14.25 \mathrm{~J} \mathrm{~cm}^{-2}\right)$ caused a phototoxic effect (Table 3). Strikingly, even irradiation at $595 \mathrm{~nm}$ $\left(2 \mathrm{~h}, 22.47 \mathrm{~J} \mathrm{~cm}^{-2}\right)$ generated a phototoxic effect in cells. It has to be noted that the lack of $\mathrm{CO}_{2}$ atmosphere during irradiation also contributed to the obtained results. Nevertheless, the calculated PI values are reliable, as cells used as dark control were also incubated for the same amount of time at $37^{\circ} \mathrm{C}$ in non- $\mathrm{CO}_{2}$ atmosphere. Worthy of note, the compound lost its phototoxic effect upon irradiation at $620 \mathrm{~nm}\left(30 \mathrm{~min}, 3.3 \mathrm{~J} \mathrm{~cm}^{-}\right.$ ${ }^{2}$ ). Interestingly, previous studies have shown that photosensi- any of them (Figure 4a). Correlation analysis including Pearson's R value as well as Manders' M1 and Manders's M2 values confirmed the lack of colocalisation of the tested probes with complex 6 (Figure $4 \mathrm{~b}$ ). It is possible that the cytosolic localisation of our complex could be explained by its binding to the cytoskeleton as recently reported for structurally similar complex by the group of MacDonnell. ${ }^{68}$

To further study the mechanism of action of complex $\mathbf{6}$, its influence on cellular metabolism was studied. For that purpose Seahorse XF instrument was used, it allows for real time measurements of oxygen consumption rate (OCR) and extracellular acidification rate (ECAR) in cells. To observe the effect of the compound $\mathbf{6}$ on oxidative phosphorylation (ATP production in mitochondria through electron transport chain), the Mito Stress test (Figure 5a) was performed. In this test, sequential injections of specific inhibitors of the electron transport chain proteins allows for determination of the effect that the compound has on the mitochondrial metabolism of the tested cells. Briefly, the cells were treated $(4 \mathrm{~h}, 1 \mu \mathrm{M})$ with 
complex 6 as well as with cisplatin and 5-ALA (5aminolevulinic acid) - precursor of protoporphyrin IX (PpIX), a known photosensitizer, as controls. ${ }^{69}$ After the incubation time, the cells were irradiated at $595 \mathrm{~nm}\left(2 \mathrm{~h}, 22.47 \mathrm{~J} \mathrm{~cm}^{-2}\right.$, see Figure S53) and the Mito Stress Test was performed. Strikingly, the data shows that only the cells, which were treated with complex $\mathbf{6}$ and irradiated, had their metabolism impaired right after the irradiation process. Injection of oligomycin (a specific inhibitor of ATP synthase) or FCCP (an uncoupling agent) did not affect their oxygen consumption rates. The mitochondrial membrane of these cells lost the capacity to restore the proton balance. ATP production was inhibited and spare respiratory capacity (difference between OCR values of maximal respiration and basal respiration) was strongly reduced, contrary to the cells treated with complex 6 that were not irradiated (Figure 5a and Figure S54).

Additional tests investigating whether the glycolysis is also affected were performed. Indeed, the glycolysis process is also severely impaired in the cells that are treated with complex 6 and irradiated (Figure 5b and Figure S55). It is known that the glycolysis process is significantly reduced during apoptosis. ${ }^{70}$ Additionally, mitochondria are important compartment, which are responsible for triggering an intrinsic cell death. ${ }^{71}$ It is then likely that the start of apoptosis is responsible for the initial effect in the cellular metabolism observed. A similar metabolic response could not be noticed for the cisplatin. This phenomenon could be explained by the short incubation time (only $4 \mathrm{~h}$ ) and the very low concentration tested $(1 \mu \mathrm{M})$ that is not sufficient to trigger apoptosis by this drug in CT-26 cell line. Overall, compound $\mathbf{6}$ has an immediate effect on irradiated cells but not in the ones kept in the dark, resulting in disturbed mitochondrial respiration and glycolysis processes.

a)

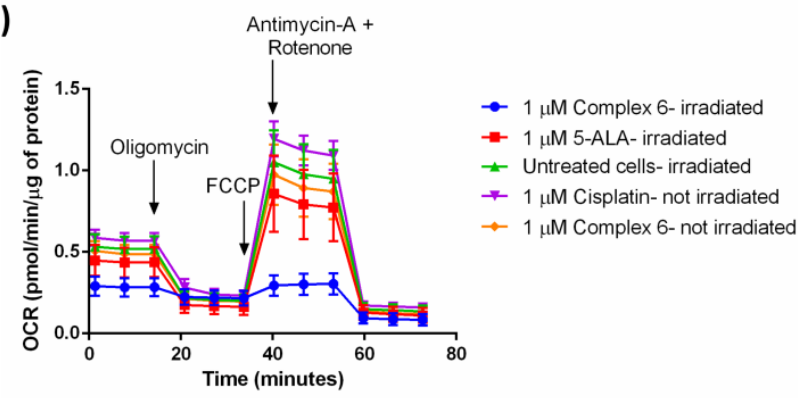

b)

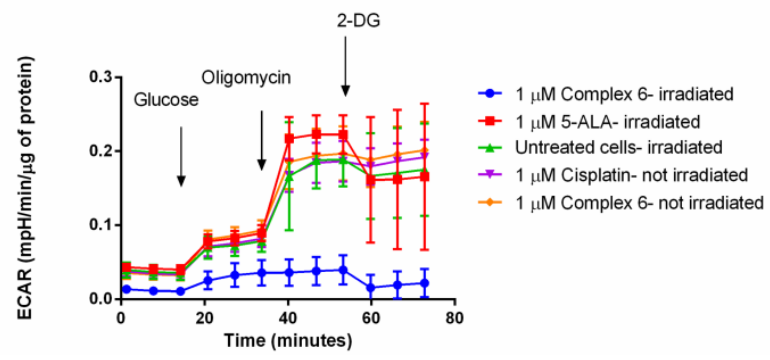

Figure 5. a) Mito Stress Test profile in CT-26 cells after $4 \mathrm{~h}$ treatment and $2 \mathrm{~h}$ irradiation at $595 \mathrm{~nm}$; oxygen consumption rate changes after treatment with specific electron transport chain inhibitors, namely oligomycin (inhibitor of ATP synthase (complex V)), FCCP (uncoupling agent), antimycin-A (complex III inhibitor) and rotenone (complex I inhibitor). b) Glycolysis Stress Test profile in CT-26 cells after $4 \mathrm{~h}$ treatment and $2 \mathrm{~h}$ irradiation at $595 \mathrm{~nm}$; extracellular acidification rate that corresponds to the glycolysis process changes after treatment with glucose (basal level of glycolysis in cells), oligomycin (inhibitor of ATP synthase (complex V)- mitochondria inhibition), 2-deoxyglucose (analog of glucose that inhibits glycolytic pathway).

After evaluation of the (photo-)cytotoxicity on 2D monolayer cells, the effect of complex 6 on multicellular tumor spheroids (MCTS) was investigated. This is of special interest as many anticancer drug candidates have failed the translation from monolayer cells to an in vivo model due to compromised drug delivery. MCTS are small spherical cell aggregates that mimic cell tumors. They can simulate the gradient of nutrients availability from upper cell layers, that are highly exposed, to lower layers and are able to model the potential penetration of a drug inside a 3D struture. ${ }^{72,73}$ Therefore, compound 6 was incubated for $24 \mathrm{~h}$ in HeLa MCTS and its cytotoxic effect determined by measurement of the ATP concentration. Importantly, upon irradiation at $595 \mathrm{~nm}\left(2 \mathrm{~h}, 22.47 \mathrm{~J} \mathrm{~cm}^{-2}\right)$, compound 6 showed a phototoxic effect $\left(\mathrm{IC}_{50 \text {,dark }}=29.42 \pm 4.60 \mu \mathrm{M}, \mathrm{IC}_{50,595 \mathrm{~nm}}=\right.$ $\left.20.07 \pm 4.15 \mu \mathrm{M}, \mathrm{PI}_{595 \mathrm{~nm}}=1.5\right)$, indicating that the compound is able to exert its action inside the 3D MCTS and act as a PDT agent. Worthy of note, the critical concentration to trigger cell death in 3D MCTS was found to be significantly larger than in 2D monolayer cells. The need for higher concentrations to cause an eradication of the MCTS was previously described in the literature, ${ }^{74}$ including for structurally related $\mathrm{Ru}$ (II) polypyridine complexes, and is assumingly caused by a poor light penetration, potential diffusion problems and/or the hypoxic center of the MCTS.

\section{CONCLUSION}

In summary, we have combined the theoretical understanding provided by DFT calculations with the photophysical and biological experimental evaluation of $\mathrm{Ru}(\mathrm{II})$ polypyridine complexes as PSs for PDT. Thanks to this rational design, ruthenium complexes with a strong red shift in their absorption profile could be successfully prepared. While the $\left(E, E^{\prime}\right)$ 4,4 '-bis $(N, N$ '-dimethylaminovinyl)-2,2'-bipyridine coordinated complexes showed the desired red shift, they were however found to have poor photophysical properties (luminescence, ${ }^{1} \mathrm{O}_{2}$ production) and poor stability. In contrast, the $\left[\mathrm{Ru}(\mathrm{bphen})_{2}(\mathrm{bmb})\right]^{2+}$ complex was found to have an absorption tail towards the biological spectral window. While being stable in human plasma as well as upon light irradiation, it was found to localize in the cytoplasm of HeLa cells. Upon irradiation at clinically relevant $595 \mathrm{~nm}$ it led to the disturbance of mitochondrial respiration and glycolysis process in 2D monolayer cells as well as 3D MCTS. We strongly believe that the approach presented here for the rational design of compounds holds great potential for the development of new PDT agents. The prediction of the photophysical properties of potential PSs enables a directed search for efficient compounds. We are planning to investigate the in vivo efficiency of compound $\mathbf{6}$ in the future.

\section{ASSOCIATED CONTENT}

The Supporting Information is available free of charge via the Internet at http://pubs.acs.org.

Detailed experimental protocols, supporting figures and tables.

\section{AUTHOR INFORMATION}




\section{Corresponding Author}

*spingler@chem.uzh.ch

*Ilaria.ciofini@chimieparistech.psl.eu

*gilles.gasser@ chimieparistech.psl.eu; www.gassergroup.com;

Tel. +33144275602.

ORCID-ID:

Johannes Karges: 0000-0001-5258-0260

Franz Heinemann: 0000-0001-9590-443X

Federica Maschietto: 0000-0002-5995-2765

Marta Jakubaszek: 0000-0001-7590-2330

Chloé Subecz : 0000-0001-8510-4818

Mazzarine Dotou: 0000-0001-87814-6763

Olivier Blacque: 0000-0001-9857-4042

Bruno Goud: 0000-0003-1227-4159

Emilio Viñuelas Zahínos: 0000-0003-0634-1829

Bernhard Spingler: 0000-0003-3402-2016

Ilaria Ciofini: 0000-0002-5391-4522

Gilles Gasser: 0000-0002-4244-5097

\section{ACKNOWLEDGMENT}

We thank Dr. Philippe Goldner for access to state-of-the-art laser apparatus. This work was financially supported by an ERC Consolidator Grant PhotoMedMet to G.G. (GA 681679) and has received support under the program "Investissements d' Avenir" launched by the French Government and implemented by the ANR with the reference ANR-10-IDEX-0001-02 PSL (G.G.). I.C and F.M. gratefully acknowledge the European Research Council (ERC) for funding (ERC Consolidator Grant STRIGES to I.C., GA No 648558).

\section{ABBREVIATIONS}

PDT, Photodynamic Therapy; PS, Photosensitiser; ROS, reactive oxygen species; ${ }^{1} \mathrm{O}_{2}$, singlet oxygen; dmb, 4,4'-dimethyl-2,2'bipyridine; IP-TT, 2-(2',2":5",2' "'-terthiophene)-imidazol[4,5f][1,10]phenanthroline; phen, 1,10-phenanthroline; bphen, 4,7diphenyl-1,10-phenanthroline; bipy, 2,2'-bipyridine; MLCT, metal to ligand charge transfer; EDG, electron donating group; EWG, electron withdrawing group; LE, ligand centered; GS, ground state; ES, excited state; ${ }^{1} \mathrm{O}_{2}$, singlet oxygen; $\log P$, distribution coefficient; PI, phototoxic index; ICP-MS, inductively coupled plasma mass spectrometry; HeLa, human cervical carcinoma cell line; CT-26, mouse colon carcinoma cell line; U87 human glioblastoma cell line, U373, human glioblastoma astrocytoma cell line, RPE-1 retina pigmented epithelial cell line; MCTS, multicellular tumor spheroid.

\section{REFERENCES}

1. D. E. Dolmans, D. Fukumura and R. K. Jain, Photodynamic Therapy for Cancer. Nat. Rev. Cancer, 2003, 3, 380-387.

2. K. Plaetzer, B. Krammer, J. Berlanda, F. Berr and T. Kiesslich, Photophysics and photochemistry of photodynamic therapy: fundamental aspects. Lasers Med. Sci., 2009, 24, 259-268.

3. S. Bonnet, Why develop photoactivated chemotherapy. Dalton Trans., 2018, 47, 10330-10343.

4. R. Bonnett, Photosensitizers of the porphyrin and phthalocyanine series for photodynamic therapy. Chem. Soc. Rev., 1995, 24, 19-33.

5. T. J. Dougherty, C. J. Gomer, B. W. Henderson, G. Jori, D. Kessel, M. Korbelik, J. Moan and Q. Peng,
Photodynamic therapy. J. Natl. Cancer Inst., 1998, 90, 889-905.

6. B. W. Henderson and T. J. Dougherty, How does Photodynamic Therapy work? Photochem. Photobiol., 1992, 55, 145-157.

7. A. E. O'Connor, W. M. Gallagher and A. T. Byrne, Porphyrin and Nonporphyrin Photosensitizers in Oncology: Preclinical and Clinical Advances in Photodynamic Therapy. Photochem. Photobiol., 2009, 85, 1053-1074.

8. A. Naik, R. Rubbiani, G. Gasser and B. Spingler, Visible-Light-Induced Annihilation of Tumor Cells with Platinum-Porphyrin Conjugates. Angew. Chem. Int. Ed., 2014, 53, 6938-6941.

9. F. Heinemann, J. Karges and G. Gasser, Critical Overview of the Use of Ru(II) Polypyridyl Complexes as Photosensitizers in One-Photon and Two-Photon Photodynamic Therapy. Acc. Chem. Res., 2017, 50, 2727-2736.

10. J. Karges, U. Basu, O. Blacque, H. Chao and G. Gasser, Polymeric Encapsulation of Novel Homoleptic Bis(dipyrrinato) Zinc(II) Complexes with Long Lifetimes for Applications as Photodynamic Therapy Photosensitisers. Angew. Chem. Int. Ed., 2019, 58, 14334-14340.

11. P. M. Antoni, A. Naik, I. Albert, R. Rubbiani, S. Gupta, P. Ruiz-Sanchez, P. Munikorn, J. M. Mateos, V. Luginbuehl, P. Thamyongkit, U. Ziegler, G. Gasser, G. Jeschke and B. Spingler, (Metallo)porphyrins as Potent Phototoxic Anti-Cancer Agents after Irradiation with Red Light. Chem. Eur. J., 2015, 21, 1179-1183.

12. P. Agostinis, K. Berg, K. A. Cengel, T. H. Foster, A. W. Girotti, S. O. Gollnick, S. M. Hahn, M. R. Hamblin, A. Juzeniene and D. Kessel, Photodynamic therapy of cancer: an update. CA Cancer J. Clin., 2011, 61, 250281.

13. S. Callaghan and M. O. Senge, The good, the bad, and the ugly - controlling singlet oxygen through design of photosensitizers and delivery systems for photodynamic therapy. Photochem. Photobiol. Sci., 2018, 17, 14901514.

14. L. Schneider, M. Larocca, W. Wu, V. Babu, R. Padrutt, E. Slyshkina, C. König, S. Ferrari and B. Spingler, Exocyclically metallated tetrapyridinoporphyrazine as a potential photosensitizer for photodynamic therapy. Photochem. Photobiol. Sci., 2019, 18, 2792-2803.

15. C. Mari, V. Pierroz, S. Ferrari and G. Gasser, Combination of $\mathrm{Ru}(\mathrm{II})$ complexes and light: new frontiers in cancer therapy. Chem. Sci., 2015, 6, 26602686.

16. S. Monro, K. L. Colón, H. Yin, J. Roque III, P. Konda, S. Gujar, R. P. Thummel, L. Lilge, C. G. Cameron and S. A. McFarland, Transition Metal Complexes and Photodynamic Therapy from a Tumor-Centered Approach: Challenges, Opportunities, and Highlights from the Development of TLD1433. Chem. Rev., 2019, 119, 797-828.

17. L. Zeng, P. Gupta, Y. Chen, E. Wang, L. Ji, H. Chao and Z.-S. Chen, The development of anticancer ruthenium(II) complexes: from single molecule compounds to nanomaterials. Chem. Soc. Rev., 2017, 46, 5771-5804.

18. L. K. McKenzie, H. E. Bryant and J. A. Weinstein, Transition metal complexes as photosensitisers in oneand two-photon photodynamic therapy. Coord. Chem. Rev., 2019, 379, 2-29. 
19.

A. Li, C. Turro and J. J. Kodanko, Ru(II) Polypyridyl Complexes Derived from Tetradentate Ancillary Ligands for Effective Photocaging. Acc. Chem. Res., 2018, 51, 1415-1421.

$20 . \quad$ J. Liu, C. Zhang, T. W. Rees, L. Ke, L. Ji and H. Chao, Harnessing ruthenium(II) as photodynamic agents: Encouraging advances in cancer therapy. Coord. Chem. Rev., 2018, 363, 17-28.

21. F. E. Poynton, S. A. Bright, S. Blasco, D. C. Williams, J. M. Kelly and T. Gunnlaugsson, The development of ruthenium(II) polypyridyl complexes and conjugates for in vitro cellular and in vivo applications. Chem. Soc. Rev., 2017, 46, 7706-7756.

22. M. Jakubaszek, J. Rossier, J. Karges, J. Delasoie, B. Goud, G. Gasser and F. Zobi, Evaluation of the Potential of Cobalamin Derivatives Bearing $\mathrm{Ru}(\mathrm{II})$ Polypyridyl Complexes as Photosensitisers for Photodynamic Therapy. Helv. Chim. Acta, 2019, 102, e1900104.

23. J. Shum, P. K.-K. Leung and K. K.-W. Lo, Luminescent Ruthenium(II) Polypyridine Complexes for a Wide Variety of Biomolecular and Cellular Applications. Inorg. Chem., 2019, 58, 2231-2247.

24. K. Qiu, Y. Chen, T. W. Rees, L. Ji and H. Chao, Organelle-targeting metal complexes: From molecular design to bio-applications. Coord. Chem. Rev., 2019 , 378, 66-86.

25. J. Karges, M. Jakubaszek, C. Mari, K. Zarschler, B. Goud, H. Stephan and G. Gasser, Synthesis and Characterization of an Epidermal Growth Factor Receptor-Selective RuII Polypyridyl-Nanobody Conjugate as a Photosensitizer for Photodynamic Therapy. ChemBioChem, doi:10.1002/cbic.201900419.

26. R. Lincoln, L. Kohler, S. Monro, H. Yin, M. Stephenson, R. Zong, A. Chouai, C. Dorsey, R. Hennigar, R. P. Thummel and S. A. McFarland, Exploitation of Long-Lived ${ }^{3} \mathrm{IL}$ Excited States for Metal-Organic Photodynamic Therapy: Verification in a Metastatic Melanoma Model. J. Am. Chem. Soc., 2013, 135, 17161-17175.

27. Y. Ellahioui, M. Patra, C. Mari, R. Kaabi, J. Karges, G. Gasser and S. Gómez-Ruiz, Mesoporous silica nanoparticles functionalised with a photoactive ruthenium(II) complex: exploring the formulation of a metal-based photodynamic therapy photosensitiser. Dalton Trans., 2019, 48, 5940-5951.

28. B. S. Howerton, D. K. Heidary and E. C. Glazer, Strained Ruthenium Complexes Are Potent LightActivated Anticancer Agents. J. Am. Chem. Soc., 2012, 134, 8324-8327.

29. J. D. Knoll and C. Turro, Control and utilization of ruthenium and rhodium metal complex excited states for photoactivated cancer therapy. Coord. Chem. Rev., 2015, 282-283, 110-126.

30. A. M. Palmer, B. Peña, R. B. Sears, O. Chen, M. E. Ojaimi, R. P. Thummel, K. R. Dunbar and C. Turro, Cytotoxicity of cyclometallated ruthenium complexes: the role of ligand exchange on the activity. Philos. Trans. R. Soc. A, 2013, 371, 20120135.

31. Theralase Annouces First Patient Treated in Phase II Non-Muscle Invasive Bladder Cancer Clinical Study, Theralase Technologies Inc., Toronto, 2019: https://theralase.com/pressrelease/theralase-annoucesfirst-patient-treated-in-phase-II-non-muscle-invasivebladder-cancer-clinical-study/ (access: 09/20/2019)

32. J. Fong, K. Kasimova, Y. Arenas, P. Kaspler, S. Lazic, A. Mandel and L. Lilge, A novel class of ruthenium- based photosensitizers effectively kills in vitro cancer cells and in vivo tumors. Photochem. Photobiol. Sci., 2015, 14, 2014-2023.

33. P. Kaspler, S. Lazic, S. Forward, Y. Arenas, A. Mandel and L. Lilge, A ruthenium(II) based photosensitizer and transferrin complexes enhance photo-physical properties, cell uptake, and photodynamic therapy safety and efficacy. Photochem. Photobiol. Sci., 2016, 15, 481-495.

34. S. A. McFarland, A. Mandel, R. Dumoulin-White and G. Gasser, Metal-based photosensitizers for photodynamic therapy: the future of multimodal oncology? Curr. Opin. Chem. Biol., 2020, 56, 23-27.

35. S. M. Cloonan, R. B. P. Elmes, M. Erby, S. A. Bright, F. E. Poynton, D. E. Nolan, S. J. Quinn, T. Gunnlaugsson and D. C. Williams, Detailed Biological Profiling of a Photoactivated and Apoptosis Inducing pdppz Ruthenium(II) Polypyridyl Complex in Cancer Cells. J. Med. Chem., 2015, 58, 4494-4505.

36. J. Karges, O. Blacque, M. Jakubaszek, B. Goud, P. Goldner and G. Gasser, Systematic investigation of the antiproliferative activity of a series of ruthenium terpyridine complexes. J. Inorg. Biochem., 2019, 198, 110752

37. H. Yin, M. Stephenson, J. Gibson, E. Sampson, G. Shi, T. Sainuddin, S. Monro and S. A. McFarland, In Vitro Multiwavelength PDT with ${ }^{3}$ IL States: Teaching Old Molecules New Tricks. Inorg. Chem., 2014, 53, 45484559.

38. E. Wachter, D. K. Heidary, B. S. Howerton, S. Parkin and E. C. Glazer, Light-activated ruthenium complexes photobind DNA and are cytotoxic in the photodynamic therapy window. Chem. Commun., 2012, 48, 96499651.

39. L. Wang, H. Yin, M. A. Jabed, M. Hetu, C. Wang, S. Monro, X. Zhu, S. Kilina, S. A. McFarland and W. Sun, $\pi$-Expansive Heteroleptic Ruthenium(II) Complexes as Reverse Saturable Absorbers and Photosensitizers for Photodynamic Therapy. Inorg. Chem., 2017, 56, 32453259.

40. K. Ogawa and Y. Kobuke, Recent advances in twophoton photodynamic therapy. Anti-Cancer Agents Med. Chem., 2008, 8, 269-279.

41. B. C. Wilson, W. P. Jeeves and D. M. Lowe, In vivo and post mortem measurements of the attenuation spectra of light in mammalian tissues. Photochem. Photobiol., 1985, 42, 153-162.

42. M. Eriksson, M. Leijon, C. Hiort, B. Norden and A Graeslund, Minor groove binding of $\left[\mathrm{Ru}(\text { phen })_{3}\right]^{2+}$ to $\left[\mathrm{d}(\mathrm{CGCGATCGCG)}]_{2}\right.$ evidenced by two-dimensional NMR. J. Am. Chem. Soc., 1992, 114, 4933-4934.

43. M. Dickerson, Y. Sun, B. Howerton and E. C. Glazer, Modifying charge and hydrophilicity of simple $\mathrm{Ru}(\mathrm{II})$ polypyridyl complexes radically alters biological activities: old complexes, surprising new tricks. Inorg. Chem., 2014, 53, 10370-10377.

44. H. Audi, D. Azar, F. Mahjoub, S. Farhat, Z. El-Masri, M. El-Sibai, R. J. Abi-Habib and R. S. Khnayzer, Cytotoxicity Modulation of Ruthenium (II) trisbathophenantholine Complexes With Systematically Varied Charge. J. Photochem. Photobiol. A, 2018, 351, 59-68.

45. S. Mehanna, N. Mansour, H. Audi, K. Bodman-Smith, M. A. Mroueh, R. I. Taleb, C. F. Daher and R. S. Khnayzer, Enhanced cellular uptake and photochemotherapeutic potential of a lipophilic strained 
Ru(ii) polypyridyl complex. RSC Adv., 2019, 9, 1725417265.

46. N. Mansour, S. Mehanna, M. A. Mroueh, H. Audi, K. Bodman-Smith, C. F. Daher, R. I. Taleb, M. El-Sibai and R. S. Khnayzer, Photoactivatable RuII Complex Bearing 2,9-Diphenyl-1,10-phenanthroline: Unusual Photochemistry and Significant Potency on CisplatinResistant Cell Lines. Eur. J. Inorg. Chem., 2018, 2018, 2524-2532.

47. S. Finck, J.-T. Issenhuth, S. Despax, C. Sirlin, M. Pfeffer, C. Poidevin, C. Gourlaouen, A. Boeglin and C. Daniel, Structural and optical properties of new cyclometalated $\mathrm{Ru}(\mathrm{II})$ derived compounds. $J$. Organomet. Chem., 2014, 760, 248-259.

48. S. Campagna, F. Puntoriero, F. Nastasi, G. Bergamini, V. Balzani, Photochemistry and Photophysics of Coordination Compounds I, ed. V. Balzani, S. Campagna, Springer Berlin Heidelberg, 2007, 117-214.

49. J. Karges, F. Heinemann, F. Maschietto, M. Patra, O. Blacque, I. Ciofini, B. Spingler and G. Gasser, A Ru(II) polypyridyl complex bearing aldehyde functions as a versatile synthetic precursor for long-wavelength absorbing photodynamic therapy photosensitizers. Biorg. Med. Chem., 2019, 27, 2666-2675.

50. G. Crosby and W. Elfring, Excited states of mixed ligand chelates of ruthenium (II) and rhodium (III). $J$. Phys. Chem., 1976, 80, 2206-2211.

51. W. E. Jones Jr, R. A. Smith, M. T. Abramo, M. D. Williams and J. Van Houten, Photochemistry of heterotris-chelated ruthenium (II) polypyridine complexes in dichloromethane. Inorg. Chem., 1989, 28, 2281-2285.

52. O. Mazuryk, K. Magiera, B. Rys, F. Suzenet, C. Kieda and M. Brindell, Multifaceted interplay between lipophilicity, protein interaction and luminescence parameters of non-intercalative ruthenium (II) polypyridyl complexes controlling cellular imaging and cytotoxic properties. J. Biol. Inorg. Chem., 2014, 19, 1305-1316.

53. W. Huang and T. Ogawa, Spontaneous resolution of $\Delta$ and $\Lambda$ enantiomeric pair of $\left[\mathrm{Ru}(\mathrm{phen})(\mathrm{bpy})_{2}\right]\left(\mathrm{PF}_{6}\right)_{2}$ (phen $=1,10$-phenanthroline, bpy= 2, 2'-bipyridine) by conglomerate crystallization. Polyhedron, 2006, 25, 1379-1385.

54. M. J. Cook, A. P. Lewis, G. S. McAuliffe, V. Skarda, A. J. Thomson, J. L. Glasper and D. J. Robbins, Luminescent metal complexes. Part 1. Tris-chelates of substituted 2, 2'-bipyridyls with ruthenium (II) as dyes for luminescent solar collectors. J. Chem. Soc., Perkin Trans. 2, 1984, 1293-1301.

55. V. Balzani and A. Juris, Photochemistry and photophysics of $\mathrm{Ru}(\mathrm{II})$ polypyridine complexes in the Bologna group. From early studies to recent developments. Coord. Chem. Rev., 2001, 211, 97-115.

56. O. Maury, J.-P. Guégan, T. Renouard, A. Hilton, P. Dupau, N. Sandon, L. Toupet and H. Le Bozec, Design and synthesis of $4,4^{\prime}-\pi$-conjugated [2, 2']-bipyridines: a versatile class of tunable chromophores and fluorophores. New J. Chem., 2001, 25, 1553-1566.

57. J. Karges, O. Blacque, P. Goldner, H. Chao and G. Gasser, Towards Long Wavelength Absorbing Photodynamic Therapy Photosensitizers via the Extension of a $\left[\mathrm{Ru}(\mathrm{bipy})_{3}\right]^{2+}$ Core. Eur. J. Inorg. Chem., 2019, 3704-3712.

58. J. Karges and G. Gasser, Synthesis, Characterisation and Biological Evaluation of $\pi$-Extended $\mathrm{Fe}(\mathrm{II})$ Bipyridine Complexes as Potential Photosensitizers for
Photodynamic Therapy. Inorg. Chim. Acta, 2020, 499, 119196.

59. J. Karges, P. Goldner and G. Gasser, Synthesis, Characterization, and Biological Evaluation of RedAbsorbing Fe (II) Polypyridine Complexes. Inorganics, 2019, 7, 4.

60. A. A. Abdel-Shafi, P. D. Beer, R. J. Mortimer and F. Wilkinson, Photosensitized generation of singlet oxygen from (substituted bipyridine) ruthenium (II) complexes. Helv. Chim. Acta, 2001, 84, 2784-2795.

61. D. Garcìa-Fresnadillo, Y. Georgiadou, G. Orellana, A. M. Braun and E. Oliveros, Singlet-Oxygen $(1 \Delta \mathrm{g})$ Production by Ruthenium (II) complexes containing polyazaheterocyclic ligands in methanol and in water. Helv. Chim. Acta, 1996, 79, 1222-1238.

62. M. Patra, T. Joshi, V. Pierroz, K. Ingram, M. Kaiser, S. Ferrari, B. Spingler, J. Keiser and G. Gasser, DMSO-Mediated Ligand Dissociation: Renaissance for Biological Activity of N-Heterocyclic-[Ru $\left(\eta^{6}\right.$-arene $) \mathrm{Cl}_{2}$ ] Drug Candidates. Chem. Eur. J., 2013, 19, 14768-14772.

63. M. D. Hall, K. A. Telma, K.-E. Chang, T. D. Lee, J. P. Madigan, J. R. Lloyd, I. S. Goldlust, J. D. Hoeschele and M. M. Gottesman, Say no to DMSO: dimethylsulfoxide inactivates cisplatin, carboplatin, and other platinum complexes. Cancer Res., 2014, 74, 39133922.

64. S. Keller, Y. C. Ong, Y. Lin, K. Cariou and G. Gasser, A tutorial for the assessment of the stability of organometallic complexes in biological media. $J$. Organomet. Chem., 2019, 121059.

65. S. J. Bruce, I. Tavazzi, V. r. Parisod, S. Rezzi, S. Kochhar and P. A. Guy, Investigation of human blood plasma sample preparation for performing metabolomics using ultrahigh performance liquid chromatography/mass spectrometry. Anal. Chem., 2009, 81, 3285-3296.

66. U. Basu, J. Karges, F. Chotard, C. Balan, P. Le Gendre, G. Gasser, E. Bodio and R. Malacea Kabbara, Investigation of photo-activation on Ruthenium(II)arene complexes for the discovery of potential selective cytotoxic agents. Polyhedron, 2019, 172, 22-27.

67. A. K. Renfrew, J. Karges, R. Scopelliti, F. D. Bobbink, P. Nowak-Sliwinska, G. Gasser and P. Dyson, Towards Light Activated Ruthenium-Arene (RAPTA-type) Prodrug Candidates. ChemBioChem, 2019, 20, 28762882.

68. N. Alatrash, F. H. Issa, N. S. Bawazir, S. J. West, K. E. Van Manen-Brush, C. P. Shelor, A. S. Dayoub, K. A. Myers, C. Janetopoulos, E. A. Lewis and F. M. MacDonnell, Disruption of microtubule function in cultured human cells by a cytotoxic ruthenium(ii) polypyridyl complex. Chemi. Sci., 2020, 11, 264-275.

69. K. Mahmoudi, K. L. Garvey, A. Bouras, G. Cramer, H. Stepp, J. G. Jesu Raj, D. Bozec, T. M. Busch and C. G. Hadjipanayis, 5-aminolevulinic acid photodynamic therapy for the treatment of high-grade gliomas. $J$. Neurooncol., 2019, 141, 595-607.

70. L. A. Pradelli, E. Villa, B. Zunino, S. Marchetti and J. E. Ricci, Glucose metabolism is inhibited by caspases upon the induction of apoptosis. Cell Death Dis., 2014, 5, e1406-e1406.

71. E. F. Mason and J. C. Rathmell, Cell metabolism: An essential link between cell growth and apoptosis. Biochim. Biophys. Acta, 2011, 1813, 645-654. 
72. J. Friedrich, C. Seidel, R. Ebner and L. A. KunzSchughart, Spheroid-based drug screen: considerations and practical approach. Nat. Protoc., 2009, 4, 309-324.

73. T. T. Goodman, C. P. Ng and S. H. Pun, 3-D Tissue Culture Systems for the Evaluation and Optimization of Nanoparticle-Based Drug Carriers. Bioconjugate Chem., 2008, 19, 1951-1959.
74. J. Liu, Y. Chen, G. Li, P. Zhang, C. Jin, L. Zeng, L. Ji, H. Chao, Ruthenium(II) polypyridyl complexes as mitochondria-targeted two-photon photodynamic anticancer agents. Biomaterials, 2015, 56, 140-153. 
TABLE OF CONTENT (TOC) GRAPHIC:

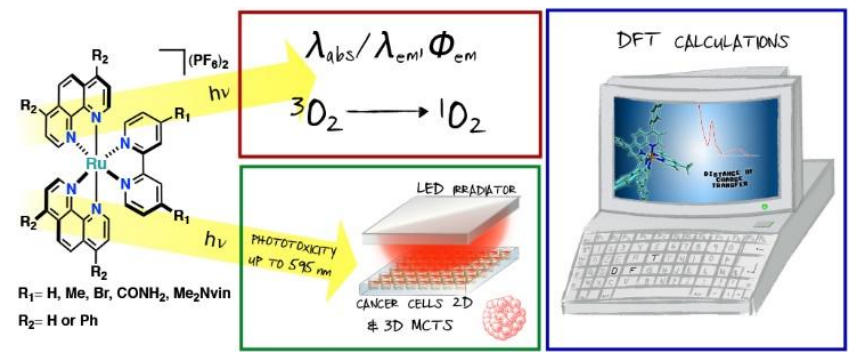

